\title{
Research on the Development Strategy of Private Enterprises from the Perspective of Political Connection
}

\author{
Jianfeng $\mathrm{Lu}^{1, \mathrm{a}}$, Ning Zhang ${ }^{2, \mathrm{~b}}$ \\ ${ }^{1}$ College of Finance and Trade, Bohai University, Jinzhou, 121013, China \\ ${ }^{2}$ China Land Surveying and Plannnig Instititue, MLR, Beijing, 100035, China \\ alujianfeng9999@126.com, b'zhangning@mail.clspi.org.cn
}

Keywords: Private enterprise; Political connection; Growth option value

\begin{abstract}
This paper makes the diversity strategic of private enterprise affected by the strong system and its change. On the one hand, due to support the formal rules of market economy has not established, the government's redistribution of power is continuing under the condition of market economy, forcing private companies to rely on political association to obtain resources and the protection of this informal system, affect the enterprise diversification decisions; This paper introduce the political association to diversified behavior analysis, found a new determinants of corporate diversification strategy, and the influence of this factor boundary, Considering the dynamics of institutional change in the economic transition, discussed the regional and industry diversification strategy of private enterprises have how much impact on enterprise performance. The paper provides strategy researchers and industry policy makers with an innovative enterprise value analysis and management tools.
\end{abstract}

\section{The Influence of Political Connection on the Industry Diversification Strategy}

In addition to the negative effect of public opinion, classical economics theory also consider enterprise's political activities as market behavior, entrepreneurs and managers put a lot of energy into the political association, is bound to affect the enterprise management and market resource allocation efficiency, however, a wide range of enterprise political associated phenomenon is inevitable objective facts, especially for private enterprises in transition economies, they have strong motivation to build political association. And no matter from political or economic perspective to analysis this phenomenon, should not avoid the interest orientation of private entrepreneurs. There are many motives for private enterprises to establish political association. May they want to seek economic benefits directly, or they want to protect their vested interests etc.

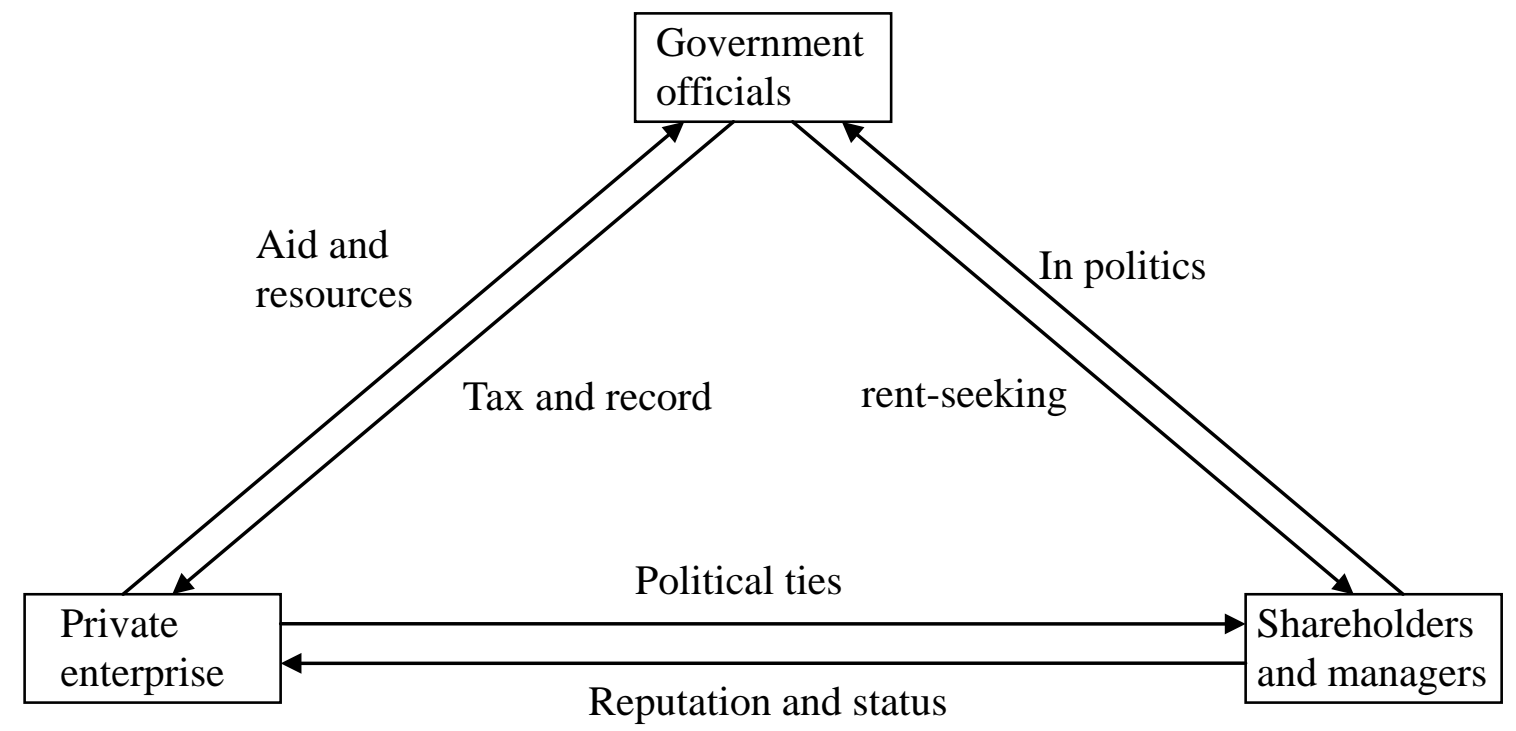

Fig.1. Interests chain between Private enterprises, government officials and enterprise senior manager The political association of the private enterprises for industry diversification strategy have a 
significant impact, if back to these findings to the based on the system of corporate diversification theory which put forward by Peng (2005), the result prove informal institutional factors indeed is one of the corporate diversification strategy. It also conforms to the system theory to explain the framework of enterprise strategic behavior, namely in the transition economies of the deficiency in the system of formal, as an alternative mechanism of private enterprises and political association plays an important role in the process of diversification in the enterprise growth. Moreover, the role of the private enterprises and political association can also good to institutional factors into the transaction cost theory and resource-based theory to explain the enterprise diversification behavior. From the point of transaction cost theory, although the transformation of economic system in the imperfect market transaction costs are high, but private enterprises through political association can reduce the business transaction costs of entry into multiple regional and industry market at the same time, so companies can give full play to the enterprise internal market resource allocation function. From the point of resource based theory, transformation of economic system environment has changed the enterprise pursuit of capabilities and resources, private enterprises through establishment political relevance is equivalent to have capacity of the market segmentation of bankruptcy and industry regulatory resources, if the non-market type and ability of resource abundance, so they will, of course, in the process of continue to diversify to maximize the use of these resources and capabilities.

\section{The Negative Effect of the Non Unified Market}

One of the most important goals of China's transition from the planned economy system to market economy system is to construction of a unified national market. If there is really such a fully unified and complete system domestic market, so private enterprises only need to use its core competitiveness to oriented. Marketing ability and production capacity, for example, transferred to other domestic areas, through the enterprise internal efficiency and execution will integrate the regional market, can occupy the Chinese market. In fact, China is not a unified market, the integration of China's domestic market is quite incomplete, common industry market segmentation, and local protectionism is serious, the existence of the local protection restricts the China's national economy run (ZeLin huang, 2006). Young (2000) analysis of provincial economic structure data, made an extreme claims: in the past 20 years of economic reform, China has developed into a "division domestic market under local officials control". So for private enterprises in terms of geographical diversification strategy, since there are serious defects of formal market economic system, they would find instead system, the relationship between government officials and executives is a key part of the formal institutional factors (Oliver, 1997), which is one of this article research premise.

When private enterprises cross-regional sales or investment in the domestic market, in order to prevent the opportunism and reduce uncertainty, private enterprises need to interaction frequently with the local government, political association offers this kind of interactive channels, help enterprises to establish and maintain a strong relationship network. Through highly political association for strong relation network can not only overcome market segmentation leads to high market transaction costs, but also advantageous to knowledge transfer and sharing resources between enterprise and local organizations, improve the legitimacy of the enterprise to survive in the local. On the contrary, the private enterprises which lack of political sensitivity is hard to do big in China's domestic market, Acemoglu, Johnson and Mitton (2009), according to a study by weaker areas in the property rights, the enterprise showed higher tendency of industry vertical integration. Fan (2009) consider system differences in various provinces in China, each region of the legal system and market development has remarkable effect on the motivation of vertical integration.

Because of the different resources endowment, social consciousness and opening time, the government of the backward area all want to be able to catch up with the development strategy. Especially under the condition of separation of powers, in order not to let the developed regions use its comparative advantage in technology from domestic trade to share a larger interests, backward regions not to join the domestic regional division of labor system, in order to in exchange for catch 
up time the local protectionism has been carry out in the backward regions. The logical of this catching up strategy spread resulted in the serious market segmentation between domestic regions.

\section{Intervention of Local Government Destroys the Market Order}

In the process of institutional transition of China's reform of decentralization type, every local government strive for different levels of economic management authority from the central government, can control the industry access and allocation of resources, etc., but there are game relation between the central government on the use of these power. In the game, the central government is the makers and generalization of the system, the local government is a bridge which connected the central macro policies and micro enterprise organization, it is also the local government intervention makes progressive reform to run smoothly.

Because the reform has not constructed the mechanism which constraint the power and the interests of the local governments at the same time, combined with the regional economic growth as the basis index of local government officials for assessment and promotion, the local government as a relatively independent regional interests' subject consciousness, position and function is reinforced. As the redistribution of the central government and local government interests, under the principle of self-interest maximization of local government, have the power to intervene and regulate enterprise activities. In order to maximize their own interests as soon as possible in the short term, they will support a number of local enterprises as soon as possible. In fact, the competition between local governments is more at the provincial level, they relax the enter condition for those private enterprises who have the province political background, can be understood as a form of competition between government, after all, the development of private enterprises can greatly promote the development of local economy, also very helpful for government tax contribution, employment and social stability, promotion of government officials.

As a result, the hierarchical characteristics of the political system as a mechanism of action, many private enterprises in varying degrees influence by the government's vertical hierarchical structure

\section{The Political Connection Has Hindered the Promotion of the Private Enterprises Competitiveness}

China's private enterprises take prominent main business, pooling resources, not scattered in multiple industry strategy. But most strategic choice and the management pattern of the private enterprise is limited to informal institutional factors, namely political association. Private enterprise's political relevance has the remarkable effect on industry diversification, this means that the political association is one of the main motivations of diversified business industry. However, the private enterprises political association to promote industry diversification is a negative response to economic globalization. on the one hand the core of the strategy is through political association enter into the industry which is low degree of market level, to avoid competition of the multinational corporation; On the other hand is through political associations enter into the industry which controlled by local government, to avoid competition.

Although multinational companies enter China first will choose competitive industries and potential industry globalization, market segmentation can temporarily provide a firewall for private enterprises to resist or delay the threat of multinational companies, but the private enterprises shouldn't use the competitive advantage of domestic market scale l, and handed it to multinational company, lost the foundation of international competitiveness. Chose the path of growth and this part of the private enterprises strategic intent is: if they can establish and maintain good relationship with local government, then make full use of government relations platform produced by the scope of economic benefits, from the local government got a lot of development opportunities and preferential policies. So they tend to put all its resources and business activities in the region to carry out the strategy of industry diversification. Thus, the success of this strategy depends on the implementation of the strategy of the enterprise's ability to dynamically build and keep good 
relationship with local government.

Especially for private enterprises in China, they must also face the institutional discrimination in the transitional economy and constantly seek institutional legitimacy of enterprises to protect private property rights from infringement. These non market support system defects led to the market to lower transaction costs, business to provide support and guarantee of the formal system, these features will be in a great extent influence in the behavior of economic subject behavior pattern and strategic choice.

\section{Conclusion}

The development of private enterprises will be threatened by a certain space, because they are depend on market segmentation, and scattered resources will cause the lack of competitiveness in every industry. At the same time, those who do not actively respond to market segmentation, low-alcohol geographic diversification of private enterprises will be difficult to achieve economies of scale because of small market share, due to the lack of international competitiveness, when in the face of the challenge of economic globalization will be in a very passive situation. But once the formal system is perfect, in the region of a high degree of market level, the influence of informal institutional factors has been greatly weakened. This shows that in the process of the market transformation, therefore through political association to realize industry diversification for private enterprise is not sustainable, it is negative response to economic globalization competition strategy, so private enterprises should pay attention to the political change trend of correlation function, to rethink the diversification strategy choice.

System can be divided into formal system and informal system, both in completely different behavior restraint mechanism to promote the enterprise's behavior and interaction. "Distributed" and "gradual" economy reform of China's transition from the planned economy to market caused serious regional market segmentation and numerous industry open opportunity, in the process, the order of market mechanism and the redistribution mechanism change, the intense collision between formal system and informal system make more unexpected amplification effect. On the one hand, it is the result of economic transition, as a formal system of redistribution mechanism has been broken, at the same time, the new formal rules of market economy has not been fully established, on the other hand, the government who has redistribution power continues to play important role under the condition of the market economy, but the original planned economy period constraint its power ideology has disintegrated, return to traditional social relationships "pattern of difference sequence" standard, makes this informal system logical grafting to government redistribution mechanism.

\section{References}

[1] Chen, C. J. P., Z. Li X. Su, and Z. Sun. Rent-Seeking Incentives, Corporate Political Connections, and the Control Structure of Private Firms .Journal of Corporate Finance,2011,17(2): 229-243.

[2] Chaney P, Faccio M, Parsley D. The Quality of Accounting Information in Politically Connected Firms .Journal of Accounting and Economics, 2011.,51(1-2):58-76.

[3] Morschett, D., Schramm-KIein, H., Swoboda,B. Decades of Research on Market Entry Modes: What Do We Really Know about External Antecedents of Entry Mode Choice?[J] journal of International Management, 2010,16(1):60-77.

[4] Goldman. E., J.Rocholl and J. So. Do Politically Connected Boards Affect Firm Value?. Review of Financial Studies,2009,22(6): 2331-2360.

[5] Ferguson, T., and H. J. Voth. The Value of Political Connections in Nazi Germany. Quarterly Journal of Economics,2008,123(1): 101-137.

[6] Wan W. P., Hoskisson R. E., Short J. C. et al. Resource-Based Theory and Corporate Diversification[J]. Journal of management. 2011, 37(5): 1335-1368. 